\title{
A MUDANÇA NA SITUAÇÃO POLÍTICA DO BRASIL E O RECRUDESCIMENTO DAS LUTAS SOCIAIS
}

\section{José Maria Almeida}

Central Sindical e Popular/Coordenação Nacional de Lutas (CSP/Conlutas)

Partido Socialista dos Trabalhadores Unificado (PSTU)

\section{A MUDANÇA NA SITUAÇÃO POLÍTICA DO BRASIL E O RECRUDESCIMENTO DAS LUTAS SOCIAIS}

Resumo: O texto trata das mobilizações multitudinárias vividas em junho e julho de 2013 no Brasil. Compreende-as como expressão espontânea da revolta de jovens e trabalhadores contra "tudo que está aí". Enfatiza que tais mobilizações conseguiram derrotar (politicamente) a repressão e acuar o governo, gerando uma mudança na relação de forças na sociedade.

Palavras-chave: Lutas sociais, organização, trabalhadores, governo.

THE CHANGE IN POLITICAL SITUATION OF BRAZIL AND THE RECRUDESCENCE OF THE SOCIAL STRUGGLES Abstract: The paper addresses the multitudinous mobilizations experienced in June and July 2013 in Brazil. Understood as spontaneous expression of the revolt of youth and workers against "all that is there." Emphasizes that such mobilizations managed to defeat (politically) the repression and corral the government, causing a change in the balance of powers in society.

Keywords: Social struggles, organization, workers, government. 


\section{INTRODUÇÃO}

Durante muitos anos o país viveu uma relativa estabilidade política, com forte controle da sociedade nas mãos da classe dominante que soube se utilizar muito bem da disposição e determinação dos governos do PT em colaborar para a manutenção do "status quo". Esta situação começa a mudar substancialmente com o amplo processo de mobilização social que eclodiu no país no mês de junho, que começou a partir de reivindicações relacionadas ao preço e qualidade do transporte coletivo e desdobrou-se em mobilizações multitudinárias, expressando uma gama enorme de descontentamentos e demandas da juventude e dos trabalhadores brasileiros.

\section{AS MOBILIZAÇÕES MULTIDINÁRIAS DE JUNHO E JULHO DE 2013 NO BRASIL}

Foram mobilizações em grande medida espontâneas, que ganharam massividade e se generalizaram a partir da brutal repressão policial a uma manifestação em São Paulo e se estenderam para todo o país. A mobilização conseguiu derrotar (politicamente) a repressão e acuou governos municipais, estaduais e o próprio governo federal, gerando uma mudança na relação de forças na sociedade. Obviamente, as rebeliões dos operários da construção civil nas grandes obras de infraestrutura que havíamos acompanhado meses antes, bem como diversas outras fortes mobilizações que ocorreram no país antes deste período, num certo sentido, já eram o prenúncio do que estava por vir.

Mas é o processo de junho que permite um salto de qualidade, com os trabalhadores saindo da letargia que caracterizou o período de estabilidade política, e passando à ofensiva política na sociedade e colocando os governos e a burguesia de forma geral na defensiva no cenário político nacional. $O$ Brasil, com esse processo, aproxima-se mais da realidade política mundial, marcada pelas rebeliões populares do norte da África e Oriente médio e das lutas de massas na Europa contra os planos de ajuste impostos pela EU, FMI e BCE.

As mobilizações multitudinárias vividas neste período foram essencialmente expressão espontânea da revolta de jovens e trabalhadores contra "tudo que está aí". Não foi um processo organizado e com objetivos políticos definidos, e por isso mesmo com muitas confusões, como o rechaço a toda e qualquer forma de organização, sejam sindicais ou políticas. Confusões, diga-se de passagem, de fundo progressivo, pois expressavam o repúdio das pessoas à bandalheira da política e políticos tradicionais, bem como das burocracias sindicais, que só atuam contra os interesses da juventude e dos trabalhadores.
E foram então, as manifestações massivas de rua, os meios de luta que predominaram naquele momento. Num segundo momento, apesar do enorme freio que a maioria das direções sindicais tentaram impor ao movimento, saíram á luta os trabalhadores organizados. Dia 27 de junho a CSP-Conlutas convocou um dia nacional de lutas, com greves e manifestações em todo o país, em apoio às demandas de junho e acrescentando outras reivindicações dos trabalhadores. Em 11 de julho houve outro dia de greves e paralisações com forte participação da classe operária, agora convocada conjuntamente por todas as centrais sindicais, em defesa de uma pauta acordada unitariamente.

Deste processo há de se destacar duas coisas. A primeira é que é preciso valorizar muito as novas formas de luta e de organização, que inevitavelmente surgem sempre que há uma mudança desta magnitude na situação política e na luta de classes. Os novos organismos surgidos neste processo (Bloco de Lutas em Porto Alegre, Assembleias Populares em belo Horizonte e no Rio de Janeiro, etc) devem ser valorizados e estimulados, pois apontam no sentido da auto-organização e autodeterminação da juventude e dos trabalhadores. Trata-se de preparar o futuro, são organizações mais avançadas dos que as que temos hoje.

Fazer isso, por outro lado, não pode nos levar a substituir a realidade pela nossa vontade. São ainda muito incipientes estes organismos, são frágeis e de difícil sobrevivência em uma eventual diminuição das mobilizações massivas. A realidade, aliás, vem apontando para esta diminuição da massividade das mobilizações, e não porque a situação política esteja retrocedendo, mas porque o processo vai se expressando de outras formas (ao invés de mobilizações massivas, milhares de pequenas mobilizações espalhadas pelo país, greves, ocupações mais radicalizadas que antes, etc, etc).

Isso remete a outra questão, que é evitar a confusão existente entre o descontentamento existente com as antigas organizações e o fim do papel político que elas podem cumprir na luta dos trabalhadores e da juventude. As grandes organizações sindicais hoje são, sim, um entrave para as lutas dos trabalhadores e da juventude, e precisam ser superadas, Não por outra razão estamos construindo a CSP-Conlutas (que, como que prevendo o que viveríamos nos dias atuais, organiza sindicatos, movimentos populares, organizações da juventude, de luta contra o machismo, o racismo e a homofobia, etc). Mas elas não estão mortas, e muito menos os sindicatos.

É ainda a estas organizações que os trabalhadores acorrem quando querem ir à luta, portanto é aí que se dará ainda, por um tempo que não tenho como definir neste momento, a disputa pela consciência dos trabalhadores, seja para 
organizar e fazer avançar a sua luta seja para leválos a superar politicamente essa direção, que ao invés de instrumento é trava contra suas lutas. A disputa pelos sindicatos, o recurso aos instrumentos políticos da unidade de ação e da frente única, portanto, são ainda necessários enquanto persistir esse quadro.

Por outro lado, concluir do rechaço aos políticos nas manifestações de junho, que partido político é forma de organização ultrapassada seria outro erro. É justa a revolta contra os políticos e partidos tradicionais, pois o que as massas veem nestes partidos, particularmente depois da traição do PT, é só corrupção e abandono das demandas do povo para atender os interesses dos grandes empresários. Mas isso é só uma parte do problema.

\section{CONCLUSÃO}

A história da luta da nossa classe já nos ensinou que, além das organizações de massa, que precisam ter um caráter de frente único em razão da função que cumpre esse tipo de organização na luta de classes (unir a todos os trabalhadores e explorados para lutar em defesa de seus interesses comuns, independentemente de suas posições políticas e ideológicas), nossa classe precisa também de uma direção política e ideológica para que sua luta evolua da luta econômica cotidiana até a luta política capaz de destruir a sociedade capitalista e avançar no sentido da construção de uma sociedade igualitária e socialista. E a experiência histórica da nossa classe já demonstrou que o partido político, revolucionário, é a forma adequada da organização para dar conta dessa tarefa.

A segunda questão que queria destacar é a perspectiva política deste processo. Abriu-se uma nova situação política no país, com os trabalhadores e jovens na ofensiva, e é preciso atuar de forma consciente para que o processo avance no sentido de aprofundar o questionamento hoje feito pelas massas a tudo que está aí. E, no bojo do processo, afirmar uma alternativa de classe e socialista, única, capaz de responder de forma completa às demandas que surgiram nas ruas no mês de junho. Esta é a tarefa de todas as organizações, sindicais, sociais e políticas da classe trabalhadora neste momento.

Isso implica estabelecer um plano de ação que estimule a continuidade, a unificação e o aprofundamento das lutas de todos os setores explorados e oprimidos do país, para derrotar o modelo econômico que hoje se aplica no país e o governo que o sustenta. E para afirmar, no lugar de tudo que aí está, uma alternativa da nossa classe que aponte para as transformações sociais necessárias no país para que o povo tenha uma vida digna e a juventude um futuro.

\section{José Maria Almeida}

Metalúrgico

Membro da Coordenação Nacional de Lutas (Conlutas)

Presidente do Partido Socialista dos Trabalhadores Unificado (PSTU)

E-mail: manoel77@yahoo.com.br

Central Sindical e Popular/Coordenação Nacional de Lutas - CSP/Conlutas

cspconlutas.org.br

Partido Socialista dos Trabalhadores Unificado - PSTU

Sede Nacional

Avenida Nove de Julho, 925

Bela Vista - Metrô Anhangabaú

CEP: 01313-000

São Paulo-SP 